Open Access, December 2020

p-ISSN : 2087-9423

e-ISSN : 2620-309X
J. Ilmu dan Teknologi Kelautan Tropis, 12(3): 849-862

http://journal.ipb.ac.id/index.php/jurnalikt

DOI: http://doi.org/10.29244/jitkt.v12i3.32199

\title{
ESTIMASI KANDUNGAN STOK KARBON PADA EKOSISTEM PADANG LAMUN DI PERAIRAN DOMPAK DAN BERAKIT, KEPULAUAN RIAU
}

\author{
ESTIMATION OF CARBON STORAGE IN THE SEAGRASS MEADOWS \\ ECOSYSTEM OF DOMPAK AND BERAKIT WATERS, RIAU ISLANDS
}

\author{
Putri Restu Hertyastuti ${ }^{1}$, Risandi Dwirama Putra ${ }^{1}$, Tri Apriadi ${ }^{2}$, Mario Putra \\ Suhana ${ }^{1}$, Fadhliyah Idris ${ }^{1}$, \& Aditya Hikmat Nugraha ${ }^{{ }^{*}}$ \\ ${ }^{1}$ Program Studi Ilmu Kelautan, Fakultas Ilmu Kelautan dan Perikanan, \\ Universitas Maritim Raja Ali Haji, Tanjungpinang, 29111, Indonesia \\ ${ }^{2}$ Program Studi Manajemen Sumberdaya Perairan, Fakultas Ilmu Kelautan dan Perikanan, \\ Universitas Maritim Raja Ali Haji, Tanjungpinang, 29111, Indonesia \\ *E-mail: adityahn@umrah.ac.id
}

\begin{abstract}
One of the important roles of the seagrass ecosystem is as a carbon sink from the atmosphere. Bintan Island is an area that has a fairly extensive seagrass ecosystem. This study aims to estimate the carbon content of seagrass beds from all types of seagrass and sediments in the waters of Berakit and Dompak, Bintan Island. Determination of potential carbon stock is carried out by looking at the estimated carbon stock in the sediment and biomass of seagrass including the upper part (leaves and midrib) and the bottom of the seagrass (rhizome and roots). Measurement of carbon stock in seagrass sediments was carried out using the dry ashing method (LOI) and the carbon content in seagrass biomass was measured using the conversion method using a constant. The results showed that at the Berakit station the estimated total carbon stock of sediment was $91 \mathrm{Mg}$ Corg ha ${ }^{-1}$ and $10.58 \mathrm{Mg} \mathrm{C/m}$ for the estimation of seagrass carbon content, while the Dompak station estimated total carbon stock in the sediment ranged from $103.80 \mathrm{Mg}$ Corg ha $a^{-1}$ and $3.34 \mathrm{Mg} \mathrm{C} / \mathrm{m}^{2}$ to estimate the carbon content of seagrass parts. The carbon content in the substrate is influenced by the sediment composition and the carbon content in the seagrass is influenced by the density of the seagrass.
\end{abstract}

Keywords: Bintan, biomass, carbon, seagrass, stock

\begin{abstract}
ABSTRAK
Salah satu peran penting ekosistem lamun yaitu sebagai penyerap karbon yang berasal dari atmosfer. Pulau Bintan merupakan salah satu pulau dengan hamparan padang lamun yang cukup luas. Penelitian ini bertujuan untuk mengestimasi kandungan karbon pada padang lamun yang berasal dari seluruh jenis lamun dan sedimen yang berada di perairan Berakit dan Dompak Pulau Bintan. Penentuan potensi cadangan karbon dilakukan dengan melihat estimasi cadangan karbon di dalam sedimen dan biomassa lamun meliputi bagian atas (daun dan pelepah daun) dan bagian bawah lamun (rhizome dan akar). Pengukuran stok karbon pada sedimen lamun dilakukan dengan menggunakan metode pengabuan kering atau Loss on Ignation (LOI) dan kandungan karbon pada biomassa lamun diukur menggunakan metode konversi dengan konstanta. Hasil penelitian menunjukkan pada stasiun Berakit estimasi total cadangan karbon sedimen sebesar $91 \mathrm{Mg} \mathrm{C}_{\text {org }}$ ha $^{-1}$ dan $10,58 \mathrm{Mg} \mathrm{C} / \mathrm{m}^{2}$ untuk estimasi kandungan karbon lamun, sedangkan stasiun Dompak nilai estimasi total cadangan karbon pada sedimen berkisar103,80 $\mathrm{Mg} \mathrm{C}_{\text {org }}$ ha $^{-1}$ dan 3,34 Mg C/m $\mathrm{m}^{2}$ untuk estimasi kandungan karbon bagian lamun. Kandungan karbon pada substrat dipengaruhi oleh komposisi sedimen dan kandungan karbon pada lamun dipengaruhi oleh kerapatan lamun.
\end{abstract}

Kata kunci: Bintan, biomassa, karbon, lamun, stok 


\section{PENDAHULUAN}

Fenomena pemanasan global merupakan salah satu permasalahan lingkungan aktual pada saat ini. Hal tersebut diakibatkan terjadinya peningkatan konsentrasi karbondioksida $\left(\mathrm{CO}_{2}\right)$ di atmosfer yang diiringi dengan menurunnya ruang terbuka hijau yang berfungsi sebagai penyerap dan penyimpan karbon. Peningkatan gas karbondioksida $\left(\mathrm{CO}_{2}\right)$ di atmosfer juga memicu terjadinya dampak lain seperti perubahan iklim dan meningkatnya permukaan air laut yang dapat mengancam keberlangsungan mahluk hidup di muka bumi pada masa yang akan datang.

Selain hutan yang berada di darat, laut juga memiliki peranan ekologi penting sebagai "blue carbon" (penyerap karbon). Keberadaan organisme hidup yang dapat menyerap karbon dapat membantu proses pengendapan/karbon yang terjadi di laut. Karbon yang terendapkan di laut mencapai sekitar $10 \%$ dari kapasitas yang ada dan berdasarkan penelitian yang dilakukan oleh beberapa peneliti dilaporkan dapat mencapai 2.000 $\mathrm{TgCy}^{-1}$ (Sarmiento \& Gruber, 2002).

Lamun merupakan satu-satunya tumbuhan tingkat tinggi yang mampu hidup terendam di bawah permukaan air laut. Padang lamun sebagai penyusun ekosistem pesisir memiliki kemampuan untuk menyimpan karbon (carbon storage). Ekosistem lamun dapat menyimpan stok karbon dalam jumlah besar karena didukung oleh kondisi substrat yang jenuh dengan air dan juga kemampuan lamun dalam menangkap sedimen (Duarte et al., 2005). Kondisi substrat yang selalu jenuh air menciptakan keadaan anoksik yang tidak mendukung reaksi pelepasan karbon, sehingga karbon dapat tersimpan pada ekosistem lamun dalam waktu yang lama (Gunawan et al., 2019). Rata-rata stok karbon global di lapisan sedimen permukaan ekosistem padang lamun sebesar 165,6 MgC/ha (Fourqurean et al., 2012).

Estimasi lebih lanjut terkait kemampuan ekosistem lamun dalam proses penye- rapan karbon yang terjadi di laut penting untuk dikaji. Perairan Pulau Bintan merupakan salah satu wilayah di Indonesia yang memiliki padang lamun yang cukup luas. Terdapat 10 jenis lamun yang ditemukan di Perairan Pulau Bintan (Kawaroe et al., 2016). Salah satu wilayah yang memiliki padang lamun yang luas di Perairan Pulau Bintan terdapat di Pesisir Pantai Timur Pulau Bintan dengan luas mencapai 2500 ha (Sjafrie et al., 2017).

Secara umum penelitian terkait kandungan karbon pada ekosistem lamun di Perairan Pulau Bintan sudah banyak dilakukan. Beberapa penelitian yang dilakukan banyak mengkaji terkait estimasi kandungan karbon yang berasal dari lamun saja (Irawan, 2017; Khairunnisa et al., 2018; Nugraha et al., 2019a; Halim et al., 2020). Penelitian terkait estimasi kandungan karbon yang berasal dari lamun dan sedimen padang lamun di Perairan Pulau Bintan masih sedikit dilakukan. Penelitian yang dilakukan oleh Indriani et al. (2017) di Perairan Pengudang dan Teluk Bakau Bintan mengkaji terkait kandungan karbon pada ekosistem lamun yang terfokus kepada dua jenis lamun yaitu Enhalus acoroides dan Thalassia hemprichii, selain itu juga dilakukan kajian terkait kandungan karbon yang terdapat pada sedimen. Penelitian ini akan mengkaji terkait kandungan karbon yang berasal dari sedimen di ekosistem lamun serta yang berasal dari seluruh jenis lamun yang ditemukan, umumnya terdapat lebih dari dua jenis lamun yang ditemukan pada hamparan ekosistem lamun di Pulau Bintan (Kawaroe et al., 2016). Terdapat dua lokasi pada penelitian ini yang secara umum memiliki karakteristik hidrodinamika lingkungan perairan berbeda. Perbedaan kondisi hidrodinamika lingkungan perairan berpengaruh terhadap struktur ekosistem lamun dan kemampuan dalam menyimpan karbon (Dahl et al., 2020). Penelitian ini bertujuan mengkaji pengaruh kondisi lingkungan yang berbeda terhadap penyerapan karbon pada ekosistem lamun. 


\section{METODE PENELITIAN}

\subsection{Waktu dan Tempat}

Penelitian ini dilaksanakan di perairan Dompak dan Berakit pada bulan Februari 2020. Proses perhitungan biomassa dan pengabuan dilakukan di laboratorium biologi laut FIKP UMRAH dan laboratorium Balai Perikanan Budidaya Air Payau Situbondo. Daerah Dompak memiliki karakteristik substrat berlumpur, termasuk perairan tertutup karena terdapat pulau-pulau di sekitarnya dan sangat dekat dengan daratan Pulau Bintan. Lokasi pengambilan sampel di perairan Pulau Dompak bersebelahan langsung dengan ekosistem mangrove. Perairan Berakit memiliki karakteristik substrat berpasir, termasuk perairan terbuka yang langsung menghadap ke perairan Laut Cina Selatan, kawasan ini termasuk ke dalam daerah konservasi lamun (Figure 1).

\subsection{Pengambilan Sampel dan Pengukuran Parameter Kualitas Perairan}

Data kerapatan lamun diambil pada setiap stasiun pengamatan yang terdiri dari tiga transek garis dengan masing-masing panjang sebesar $100 \mathrm{~m}$ dengan jarak antar transek garis sepanjang $50 \mathrm{~m}$, dan transek dibentangkan dari arah pantai (titik pertama kali ditemukan lamun) ke arah laut. Pengamatan kerapatan lamun pada transek garis dilakukan dengan menggunakan bantuan transek kuadrat berukuran $0,5 \times 0,5 \mathrm{~m}$ dengan jarak antar transek kuadrat sebesar $10 \mathrm{~m}$ (Rahmawati et al., 2017).

Data biomassa lamun diukur dengan cara mengambil sampel yang berasal dari setiap jenis lamun yang ditemukan pada transek pengamatan. Sampel lamun yang berasal dari lapangan dibersihkan dari organisme penempel. Sampel yang telah diber-

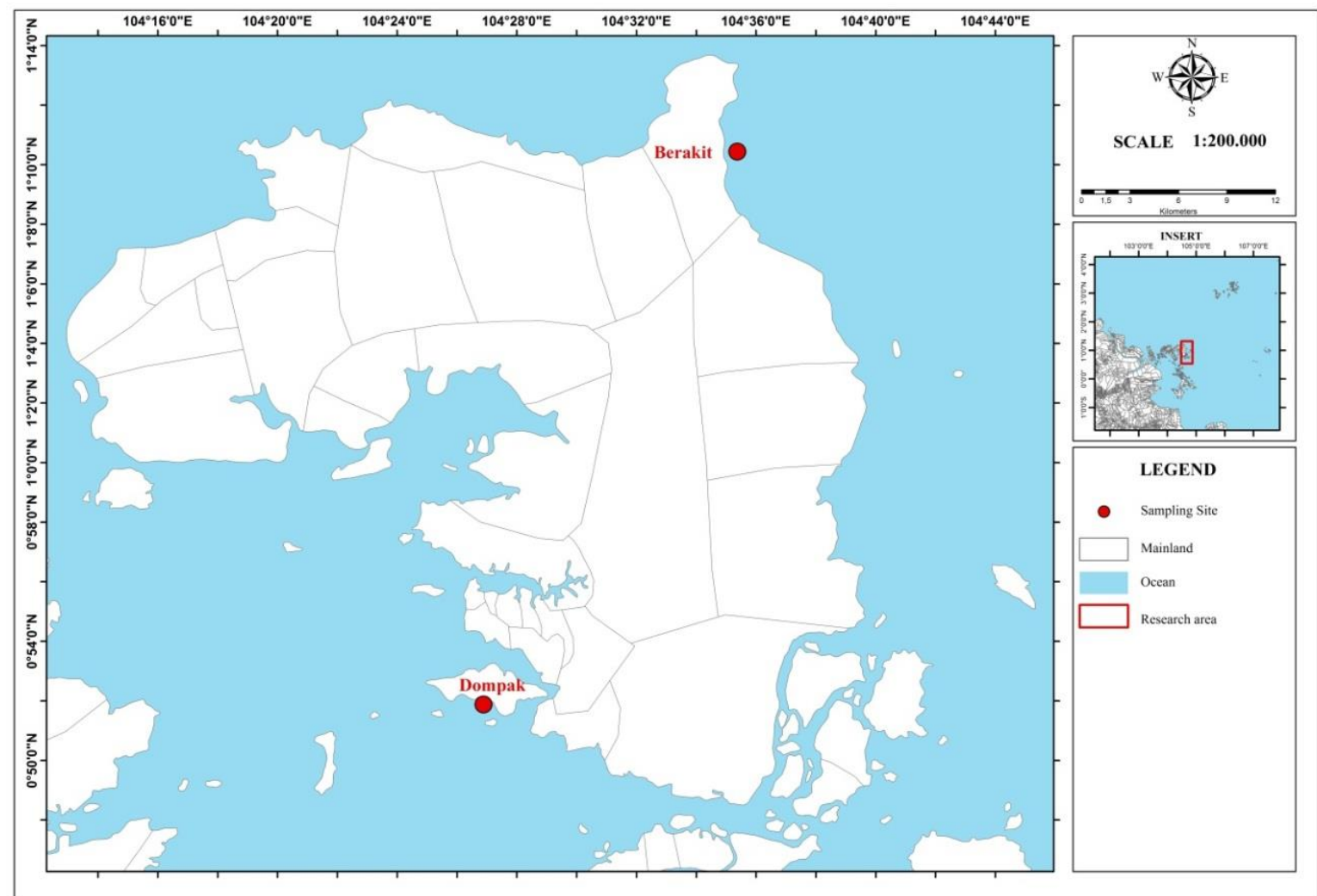

Figure 1. Sampling site in Berakit and Dompak Station. 
sihkan selanjutnya dikelompokan menjadi dua berdasarkan biomassa yang akan diamati, yaitu meliputi biomassa di atas substrat (above ground) yang terdiri atas helaian dan pelepah daun dan biomassa di bawah substrat (below ground) yang terdiri dari akar dan rhizome (Khairunnisa et al., 2018). Sampel lamun kemudian dikeringkan di laboratorium menggunakan oven pada suhu $80^{\circ} \mathrm{C}$ selama 48 jam hingga beratnya konstan.

Sampel sedimen diambil menggunakan alat sediment core yang terbuat dari PVC berukuran panjang $50 \mathrm{~cm}$ dengan diameter 2 inci. Terdapat 3 ulangan pengambilan sedimen pada setiap stasiun. Sampel yang terkumpul selanjutnya dipotong per layer dengan panjang masing-masing layer 5 $\mathrm{cm}$. Sampel sedimen selanjutnya dikeringkan pada suhu $80^{\circ} \mathrm{C}$ hingga mencapai berat konstan dan selanjutnya siap untuk dianalisis lebih lanjut.Pengukuran parameter perairan meliputi: suhu, $\mathrm{pH}$, dan oksigen terlarut diukur menggunakan multitester, sedangkan salinitas menggunakan hand refraktometer (APHA, 2017). Pengukuran dilakukan secara langsung di lapangan (in situ), sebanyak tiga kali ulangan pada setiap stasiun pengamatan.

\subsection{Analisis Data}

Kerapatan jenis lamun dihitung menggunakan persamaan sebagai berikut (Supriadi et al. 2014) :

$D=\frac{\sum n i}{A I}$

Keterangan: $D=$ kerapatan lamun $\left(\mathrm{ind} / \mathrm{m}^{2}\right)$; $\sum_{n i}=$ jumlah individu spesies lamun(ind);

$A i=$ luas area transek $\left(\mathrm{m}^{2}\right)$.

Biomassa total $\left(\mathrm{g} / \mathrm{m}^{2}\right)$ dapat dihitung dengan persamaan sebagai berikut:

$B=W \times D$

Keterangan: $B=$ total biomassa lamun $\left(\mathrm{g} / \mathrm{m}^{2}\right) ; W=$ biomassa 1 individu jenis lamun (g/tunas); $\mathrm{D}=$ kerapatan jenis lamun (ind $/ \mathrm{m}^{2}$ ).

Setelah mendapatkan nilai biomassa lamun, kemudian kandungan organik pada lamun dihitung dengan menggunakan metode konversi (Rahmawati et al., 2019a):

Carbon Concentration $=$ Biomass $x$ 0,336..

Keterangan: $B=$ total biomassa lamun $\left(\mathrm{g} / \mathrm{m}^{2}\right)$; 0,336 konstanta konversi karbon.

Pengukuran kandungan karbon organik menggunakan metode pengabuan kering (Loss on Ignition). Berikut ini persamaan untuk mengetahui bahan organik sedimen yang hilang pada proses pembakaran.

$L O I=\left(\frac{w o-w t}{w o} \times 100\right)$

Keterangan: LOI adalah Persentase dari Loss on Ignition (\%); Wo= berat awal sedimen $(\mathrm{g}) ; \mathrm{Wt}=$ berat akhir sedimen $(\mathrm{g})$.

Kandungan organik dianalisis menggunakan persamaan berikut (Rahmawati et $a l, .2019 b)$ :

$\operatorname{Corg}=0,43 \times L O I-0,33$

Keterangan: Corg $=$ Persentase kandungan karbon organik (\%).

Stok karbon per layer pada sedimen dianalisis dengan menggunakan persamaan berikut (Rahmawati et al., 2019b) :

Carbon storage in sediment $\left(g C_{\text {org }} \mathrm{cm}^{-3}\right)=$ DBD (dry bulk density) $x$ Corg (\%).

Keterangan: $D B D=$ koreksi pemadatan.

Total stok karbon pada sedimen dianalisis per sampel dianalisis menggunakan persamaan:

Total of carbon storage in sediment $\left(\mathrm{gC}_{\text {org }} \mathrm{Cm}^{-2}\right)=$ carbon storage in sediment $(\mathrm{g}$ $\left.C_{\text {org }} \mathrm{cm}^{-3}\right) \times$ sediment thickness $(\mathrm{cm}) \ldots$ (7) 


\section{HASIL DAN PEMBAHASAN}

\subsection{Karakteristik Perairan}

Parameter kualitas lingkungan merupakan salah satu yang memengaruhi karakteristik dari suatu ekosistem perairan. Pengambilan data parameter kualitas perairan meliputi suhu $\left({ }^{0} \mathrm{C}\right)$, salinitas $(\% \mathrm{oo}), \mathrm{pH}$, oksigen terlarut dissolved. oxygen/DO (mg/L), dan jenis substrat (Table 1).

Secara umum suhu di perairan Dompak dan Berakit adalah berkisar 30$32^{\circ} \mathrm{C}$. Perbedaan suhu perairan diakibatkan beberapa faktor antara lain dari sinar matahari, perbedaan geografis, sirkulasi arus, angin serta musim (Paty, 2013). Mengacu kepada baku mutu air laut untuk biota laut dalam Keputusan Menteri Negara Lingkungan Hidup No. 51 tahun 2004, maka suhu perairan Dompak dan Berakit masih berada dalam batas normal dan sesuai dengan kebutuhan untuk metabolisme biota laut dan ekosistem pesisir laut seperti karang, lamun, dan mangrove. Suhu berperan dalam memengaruhi proses proses fotosintesis, reproduksi dan memengaruhi pertumbuhan lamun (Repolho et al., 2016).

Hasil pengkuran yang didapat dari perairan Dompak dan Berakit menunjukkan nilai salinitas yang sama yaitu $34 \%$. Berdasarkan Keputusan Menteri Negara Lingkungan Hidup No. 51 tahun 2004 baku mutu salinitas perairan berkisar 33-34 \% Pengaruh salinitas terhadap tumbuhan lamun yaitu memengaruhi fisiologi lamun yang berkaitan dengan tekanan osmotik lamun dengan lingkungannya. Berdasarkan hasil pengukuran nilai $\mathrm{pH}$ perairan Dompak dan Berakit tidak menunjukkan perbedaan yang jauh. Nilai $\mathrm{pH}$ pada perairan dompak berkisar 8,3 sedangkan pada perairan Berakit berkisar 8,4 kondisi ini masih dalam kisaran yang baik untuk kehidupan lamun. Menurut Keputusan Menteri Negara Lingkungan Hidup No. 51 tahun 2004 baku mutu pH perairan berkisar 7-8,5.

Nilai $\mathrm{pH}$ di suatu perairan dapat berbeda dikarenakan oleh beberapa faktor diantaranya yaitu aktivitas fotosintesis biota laut, suhu dan salinitas perairan. Variasi nilai $\mathrm{pH}$ perairan sangat memengaruhi biota di suatu perairan. Nilai $\mathrm{pH}$ yang ideal bagi perairan adalah 7-8,5. Kondisi perairan yang sangat basa maupun sangat asam akan membahayakan kelangsungan hidup organisme karena akan mengganggu proses metabolisme dan respirasi. $\mathrm{pH}$ suatu perairan merupakan salah satu parameter kimia yang cukup penting dalam memantau kestabilan perairan (Hamuna et al., 2018).

DO diperlukan oleh semua mahluk hidup untuk proses pernapasan, proses metabolisme atau pertukaran zat yang kemudian menghasilkan energi untuk pertumbuhan dan perkembangbiakan. Kebutuhan organisme terhadap oksigen terlarut relatif bervariasi tergantung pada jenisnya (Gemilang \& Kusumah, 2017). Hasil pengukuran DO pada stasiun pengamatan cukup bervariasi yaitu berkisar 5,1-6,2 $\mathrm{mg} / \mathrm{L}$. Hasil pengukuran tersebut menandakan bahwa DO di perairan Dompok dan Berakit dalam kondisi

Table 1. Some environmental parameters from the observation sites.

\begin{tabular}{|c|c|c|c|c|}
\hline \multirow{2}{*}{ No. } & \multirow{2}{*}{ Parameter } & \multicolumn{2}{|c|}{ Site } & \multirow{2}{*}{ Standara } \\
\hline & & Berakit & Dompak & \\
\hline 1. & Temperature $\left({ }^{\circ} \mathrm{C}\right)$ & 30 & 32 & natural \\
\hline 2. & Salinity $(\%)$ & 34 & 34 & $31-37$ \\
\hline 3. & $p H$ & 8.4 & 8.3 & $7-8.5$ \\
\hline 4. & $D O(m g / L)$ & 5.1 & 6.2 & $<5$ \\
\hline 5 & Sand $(\%)$ & 95.6 & 87.54 & \\
\hline 6 & $\operatorname{Mud}(\%)$ & 1.45 & 10.09 & \\
\hline 7 & Gravel (\%) & 2.92 & 2.23 & \\
\hline
\end{tabular}


baik, sesuai untuk biota laut dan masih memenuhi standar baku mutu perairan berdasarkan Keputusan Menteri Negara Lingkungan Hidup No. 51 tahun 2004 untuk kehidupan biota laut dengan nilai DO $>5 \mathrm{mg} / \mathrm{l}$.

Berdasarkan komposisi substratnya diketahui bahwa Perairan Berakit memiliki jenis substrat yang didominasi oleh pasir sedangkan Perairan Dompak memiliki tipe substrat berupa pasir berlumpur. Kondisi dinamika perairan dan lingkungan sekitarnya berpengaruh terhadap komposisi penyusun dan dinamika substrat dasar perairan (Lanuru et al., 2018). Perairan Dompak memiliki perairan yang semi tertutup dengan karakteristik arus perairan yang relatif tenang hal tersebut berdampak kepada karakteristik substratnya yang memiliki komposisi lumpur relatif tinggi.

\subsection{Kerapatan Lamun}

Secara umum terdapat empat jenis lamun yang ditemukan pada lokasi penelitian. Berdasarkan pengamatan di lapangan setiap jenis lamun yang ditemukan memiliki nilai kerapatan berbeda (Figure 2).

Total kerapatan lamun di Stasiun Berakit yaitu sebesar $246 \mathrm{ind} / \mathrm{m}^{2}$ sedangkan stasiun Dompak memiliki kerapatan total sebesar $103 \mathrm{ind} / \mathrm{m}^{2}$. Lamun jenis $T$. hemprichii memiliki nilai kerapatan yang relatif tinggi yaitu sebesar $100 \mathrm{ind} / \mathrm{m}^{2} \mathrm{di}-$ banding lamun jenis lain. T. hemprichii merupakan jenis lamun kosmopolitan yang memiliki tingkat adaptasi yang tinggi terhadap kondisi lingkungan perairan (Short $e t$ al., 2007). Lamun jenis tersebut banyak ditemukan di sepanjang pantai timur Pulau Bintan seperti kawasan Teluk Bakau dan Malang Rapat (Adi et al., 2019; Nugraha et al., 2019b). Berbeda dengan Perairan Berakit, lamun di Perairan Dompak didominasi oleh lamun jenis Halophilla ovalis dan E. acoroides. Penelitian yang dilakukan oleh Khairunisa et al. (2018) menjelaskan bahwa lamun jenis $T$. hemprichii memiliki kerapatan lamun tertinggi dibandingkan dengan spesies lain di Perairan Berakit. Perairan Dompak memiliki kerapatan lamun yang lebih rendah dibandingkan dengan Perairan Berakit. Berdasarkan hasil pengamatan langsung di lapangan, hal tersebut diduga karena Perairan Dompak memiliki tingkat kekeruhan yang tinggi dibandingkan dengan perairan Berakit. Karakteristik dasar perairan yang memiliki campuran lumpur umumnya memiliki tingkat kekeruhan yang tinggi dibandingkan dengan perairan yang terdiri dari substrat pasir (Sarinawaty et al., 2018).

Kerapatan jenis lamun dipengaruhi faktor tempat tumbuh dari lamun tersebut. Beberapa faktor yang memengaruhi kerapa-

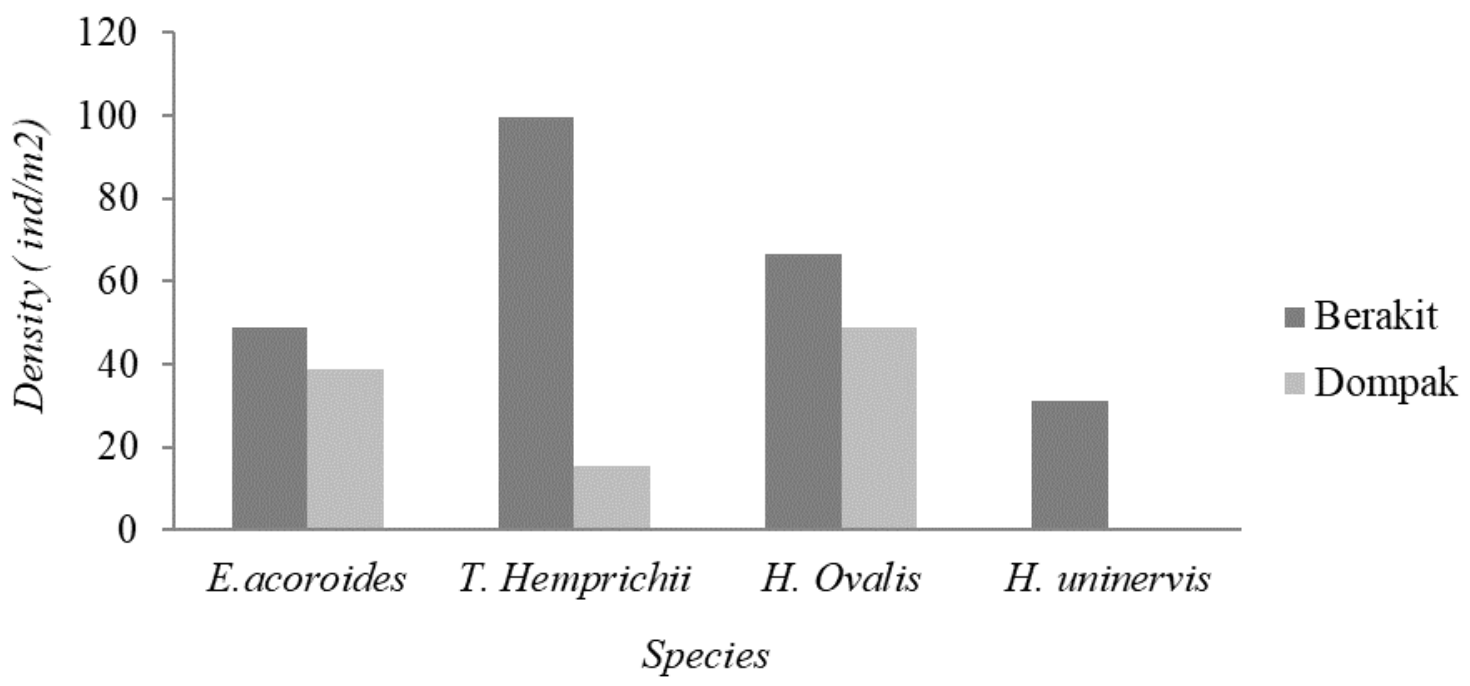

Figure 2. Seagrass species density of Dompak and Berakit Station. 
tan jenis lamun diantaranya adalah salinitas, $\mathrm{pH}$, kedalaman, arus, kecerahan, arus dan tipe substrat (Feryatun et al., 2012; Kawaroe et al., 2016). Kerapatan lamun sangat berkontribusi dalam penentuan biomassa lamun, semakin tinggi biomassa maka cadangan karbon pada ekosistem lamun akan semakin tinggi (Nugraha et al., 2019a).

\subsection{Biomassa dan Karbon}

Hasil perhitungan biomassa dan kandungan karbon yang berasal dari biomassa lamun di Perairan Dompak dan Berakit disajikan dalam Table 2.

Informasi dari Table 2 menunjukkan bahwa stasiun Berakit memiliki nilai biomassa dan karbon total lamun yang lebih tinggi dibandingkan Dompak, total biomassa di stasiun Berakit sebesar 3149,3 gBK/m², sedangkan stasiun Dompak sebesar 993,1 $\mathrm{gBK} / \mathrm{m}^{2}$. Nilai total kandungan karbon lamun di Perairan Dompak sebesar 333,75 g $\mathrm{C} / \mathrm{m}^{2}$ dan Perairan Berakit sebesar 1058,17 g $\mathrm{C} / \mathrm{m}^{2}$. Sebagai bahan perbandingan penelitian yang dilakukan oleh Indriani et al. (2017) di Pulau Bintan tepatnya di Perairan Pengudang memiliki estimasi kandungan karbon yang berasal dari lamun sebesar 68398,7 g C/m² dan di Perairan Teluk Bakau memiliki estimasi kandungan karbon sebesar $57763,47 \mathrm{~g} \mathrm{C} / \mathrm{m}^{2}$. Berdasarkan perbandingan tersebut terlihat bahwasannya setiap stasiun memiliki estimasi nilai kandungan karbon lamun yang berbeda. Hal tersebut dikarenakan perbedaan kondisi lingkungan perairan di masing-masing stasiun. Kondisi lingkungan perairan memengaruhi kualitas ekosistem lamun yang dapat berdampak kepada peran ekosistem lamun di dalam aktivitas penyerapan karbon (Wahyudi et al., 2020).

Biomassa lamun yang terletak pada bagian bawah substrat memiliki nilai yang lebih besar dibandingkan biomassa lamun yang terletak pada atas substrat. Hal tersebut tentu berdampak terhadap kandungan karbon pada tubuh lamun bagian bawah yang cenderung memiliki nilai lebih besar. Hasil penelitian Indriani et al. (2017) memperoleh hasil yang sama bahwa nilai biomassa bawah substrat lebih besar dari pada nilai biomassa atas substrat. Menurut Hartati et al. (2017) hal ini terjadi dikarenakan rhizome mengandung banyak bahan organik dimana zat tersebut didistribusikan dari proses mekanisme fotosintesis yang terjadi di bagian daun lalu diserap dan disimpan pada bagian bawah substrat, sehingga biomassa pada rhizome lebih tinggi dibandingkan dengan jaringan lainnya. Penelitian yang dilakukan Nugraha et al. (2019a) menjelaskan bahwasanya biomassa lamun yang ber-

Table 2. Total biomass dan carbon concentration of seagrass in Berakit and Dompak waters.

\begin{tabular}{|c|c|c|c|c|c|c|c|}
\hline \multirow{3}{*}{ Site } & \multirow{3}{*}{ Species } & \multicolumn{4}{|c|}{ Biomass and carbon concentration } & \multicolumn{2}{|c|}{$\begin{array}{c}\text { Total biomass and carbon } \\
\text { concentration } A G+B G\end{array}$} \\
\hline & & \multicolumn{2}{|c|}{ Above ground $(A G)$} & \multicolumn{2}{|c|}{ Below ground $(B G)$} & & \\
\hline & & $\begin{array}{l}\text { Biomass } \\
\mathrm{g} \mathrm{BK} / \mathrm{m}^{2}\end{array}$ & $\begin{array}{l}\text { Carbon } \\
\mathrm{gC} / \mathrm{m}^{2}\end{array}$ & $\begin{array}{l}\text { Biomass } \\
\mathrm{gBK} / \mathrm{m}^{2}\end{array}$ & $\begin{array}{l}\text { Carbon } \\
\mathrm{gC} / \mathrm{m}^{2}\end{array}$ & $\begin{array}{l}\text { Biomass } \\
A G+B G \\
g B K / m^{2}\end{array}$ & $\begin{array}{c}\text { Carbon } \\
A G+B G \\
g C / m^{2}\end{array}$ \\
\hline \multirow[t]{3}{*}{ Dompak } & E.acoroides & 115.57 & 38.83 & 806.9 & 667.62 & 922.47 & 309.95 \\
\hline & T.hemprichii & 13.77 & 4.63 & 22.49 & 79.39 & 36.26 & 12.18 \\
\hline & H.ovalis & 19.48 & 6.55 & 15.1 & 0.42 & 34.58 & 11.62 \\
\hline Total & & & & & & 993.31 & 333.75 \\
\hline \multirow[t]{4}{*}{ Berakit } & E.acoroides & 788.94 & 265.08 & $1,986.96$ & 2.61 & $2,775.9$ & 932.70 \\
\hline & T.hemprichii & 112.66 & 37.85 & 236.96 & 271.12 & 348.95 & 117.25 \\
\hline & H.Ovalis & 0.79 & 0.27 & 1.26 & 7.56 & 2.05 & 0.69 \\
\hline & H.uninervis & 14.62 & 4.91 & 7.78 & 5.07 & 22.4 & 7.53 \\
\hline Total & & & & & & $3,149.3$ & $1,058.17$ \\
\hline
\end{tabular}


ada pada bagian bawah substrat memiliki kandungan bahan organik yang lebih tinggi dan lebih padat dibandingkan dengan bahan organik pada tubuh lamun bagian atas

Berdasarkan informasi dalam Table 2 diketahui bahwa nilai biomassa berkontribusi terhadap kandungan karbon lamun. Diduga bahwa kerapatan lamun memiliki peran dalam memengaruhi nilai biomassa lamun dalam luasan area tertentu. Hal tersebut sesuai dengan pernyataan yang dijelaskan oleh Nugraha et al. (2019a) yakni kerapatan lamun berhubungan dengan nilai biomassa lamun yang digunakan untuk mengestimasi hasil karbon, semakin besar kerapatan lamun, maka semakin besar pula biomassa yang terdapat di dalamnya. Selain kerapatan, morfometrik lamun juga berkontribusi dalam menentukan biomassa lamun, umumnya lamun yang memiliki karakteristik morfometrik besar memiliki biomassa yang lebih besar dibandingkan lamun yang memiliki morfometrik kecil, sehingga mampu menyimpan karbon lebih besar (Rustam et al., 2017). Semakin besar ukuran lamun maka akan semakin besar biomassa, sehingga karbon yang tersimpan akan lebih besar.

\subsection{Karbon Organik pada Sedimen}

Kandungan karbon organik pada sedimen di perairan Dompak dan Berakit, dilakukan pada kedalaman 5, 10, 15, dan 20 $\mathrm{cm}$ (Figure 3).

Kandungan karbon organik pada seluruh sampel berkisar 0,36-0,40\%. Nilai kandungan karbon organik pada sedimen yang diperoleh sesuai dengan hasil kajian Fourqurean et al. (2012) yaitu kandungan karbon organik di sedimen padang lamun secara global berada pada kisaran 0-48,2\% . Informasi yang disajikan pada Figure 3 terlihat bahwasanya nilai kandungan karbon organik tertinggi terdapat di stasiun Berakit pada layer sedimen bagian atas. Hal tersebut diduga berasal dari pengaruh kerapatan lamun yang tinggi pada stasiun tersebut. Semakin besar kerapatan lamun, maka semakin besar pula biomassa yang dapat memengaruhi kandungan karbon organik di dalamnya (Harimbi et al., 2019). Hal tersebut juga dipertegas oleh hasil penelitian Kennedy et al. (2010) yang menyatakan bahwa sumber kandungan karbon organik pada sedimen ekosistem lamun di kedalaman 0-10 m berasal dari biomassa lamun.

Mayoritas karbon organik pada sedimen ekosistem lamun berasal dari serasah jaringan lamun dan sisanya berasal dari lingkungan sekitar ekosistem lamun (Rahayu et al., 2019). Serasah yang terkubur dalam sedimen berpotensi sebagai sumber karbon organik di dasar perairan. Sumber karbon

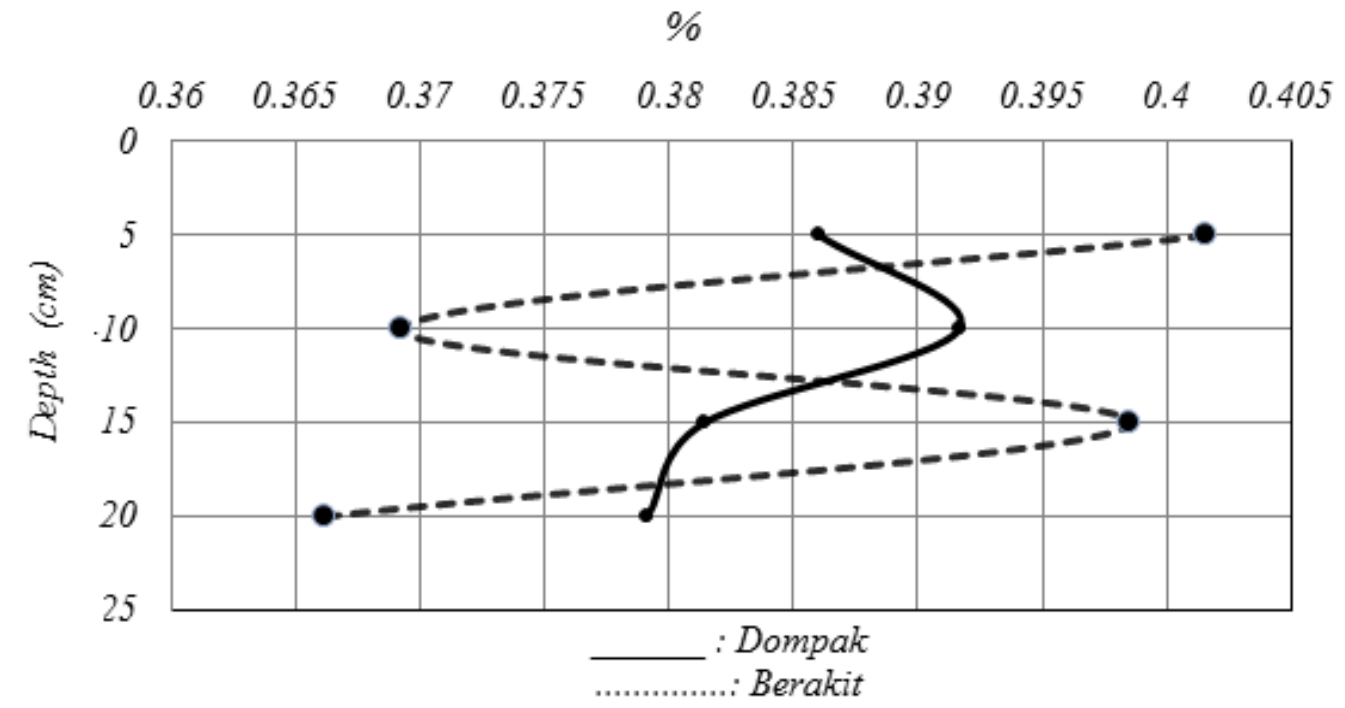

Figure 3. Percentage of Organic Carbon of Dompak and Berakit on 0-20 m depth. 
organik yang tersimpan pada sedimen di ekosistem lamun dapat berasal dari kehadiran marine snow baik yang bersifat autotochnous maupun allochtonous (Wahyudi et al., 2016).

Berdasarkan hasil analisis statistik dengan menggunakan Wilcoxon test Figure 4 , diketahui nilai $p$ value $>0.005$ sehingga dapat disimpulkan bahwa kandungan karbon organik pada sedimen di kedua lokasi tidak berbeda secara signifikan. Namun terlihat ada perbedaan stok karbon organik di sedimen pada dua lokasi (Figure 5). Dapat diasumsikan perbedaan lokasi seperti kondisi hidrodinamika perairan berpengaruh terhadap kandungan karbon organik di sedimen.

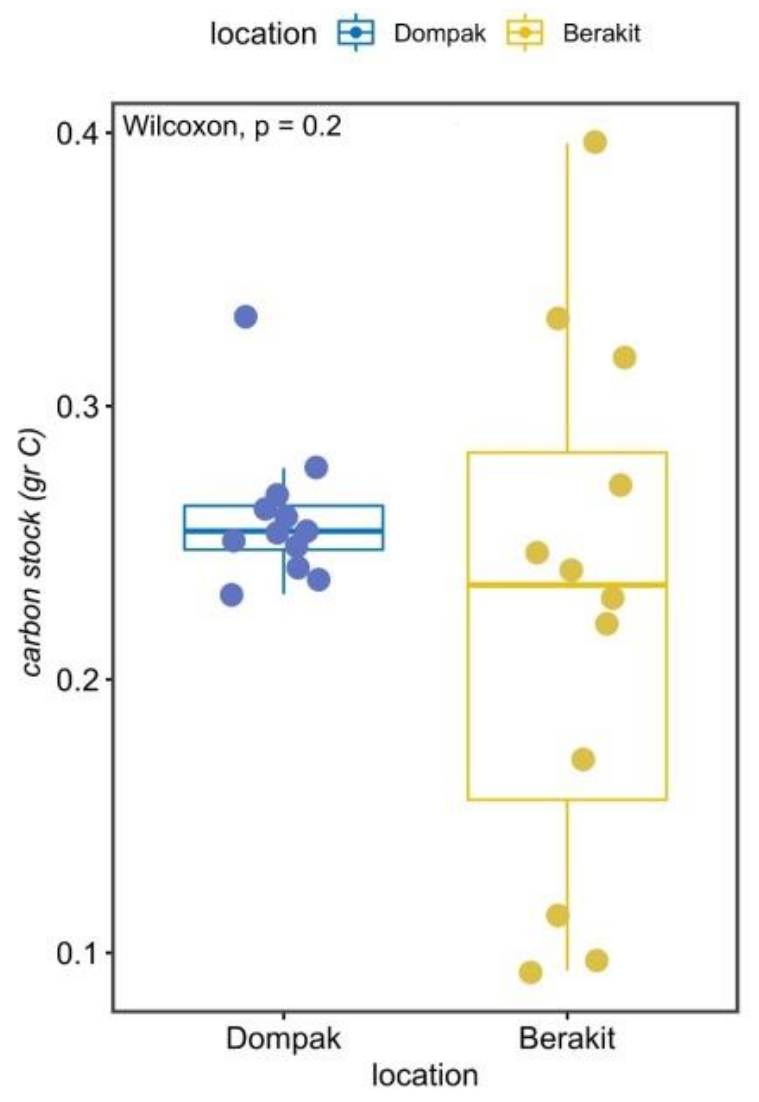

Figure 4. Willcoxon test of carbon organic content on sediment at Dompak and Berakit.

Secara umum kandungan karbon organik pada sedimen di ekosistem lamun mengalami penurunan konsentrasi seiring bertambahnya kedalaman sedimen. Peneli- tian yang dilakukan oleh Rahayu et al. (2019) di Kepulauan Speremonde memiliki pola yang sama, nilai konsentrasi karbon organik semakin menurun seiring bertambahnya kedalaman sedimen. Fenomena tersebut diduga karena adanya proses diagenesis sedimen yang menyebabkan semakin kecilnya konsentrasi karbon organik seiring bertambahnya kedalaman (Lavery et al., 2013).

\subsection{Estimasi Stok Karbon}

Estimasi kandungan stok karbon secara umum pada stasiun Dompak dan Berakit meliputi dua aspek yaitu yang berasal dari biomassa lamun dan sedimen di ekosistem lamun. (Figure 5).

Hasil yang disajikan pada Figure 5 diketahui bahwa terdapat perbedaan hasil di dua stasiun pengamatan. Stok karbon yang berasal dari biomassa lamun di Perairan Berakit memiliki nilai stok karbon lebih tinggi dari pada Perairan Dompak. Stok karbon yang tinggi di Perairan Berakit diduga berasal dari biomassa dan kerapatan lamun yang tinggi di perairan tersebut. Selain itu, lamun di Perairan Berakit juga didominasi oleh jenis yang memiliki morfometrik daun yang besar. Kerapatan dan morfometrik lamun merupakan faktor penentu dalam menentukan stok karbon yang berasal dari biomassa lamun (Rustam et al., 2017).

Estimasi stok karbon yang berasal dari sedimen di ekosistem lamun menunjukkan bahwa Perairan Dompak memiliki estimasi stok karbon lebih tinggi yaitu sebesar 103,8 $\mathrm{MgC} \quad$ ha $^{-1}$ dibandingkan dengan Perairan Berakit yaitu sebesar 91 $\mathrm{MgC} \mathrm{ha}{ }^{-1}$. Terdapat faktor lain yang memengaruhi kandungan karbon pada sedimen selain kerapatan lamun, yaitu seperti kondisi lingkungan perairan di sekitarnya (Kennedy et al., 2010; Rahayu et al., 2019). Perairan Dompak memiliki karakteristik substrat dasar perairan yang terdiri dari campuran pasir dan lumpur sedangkan perairan berakit memiliki substrat dasar yang didominasi 


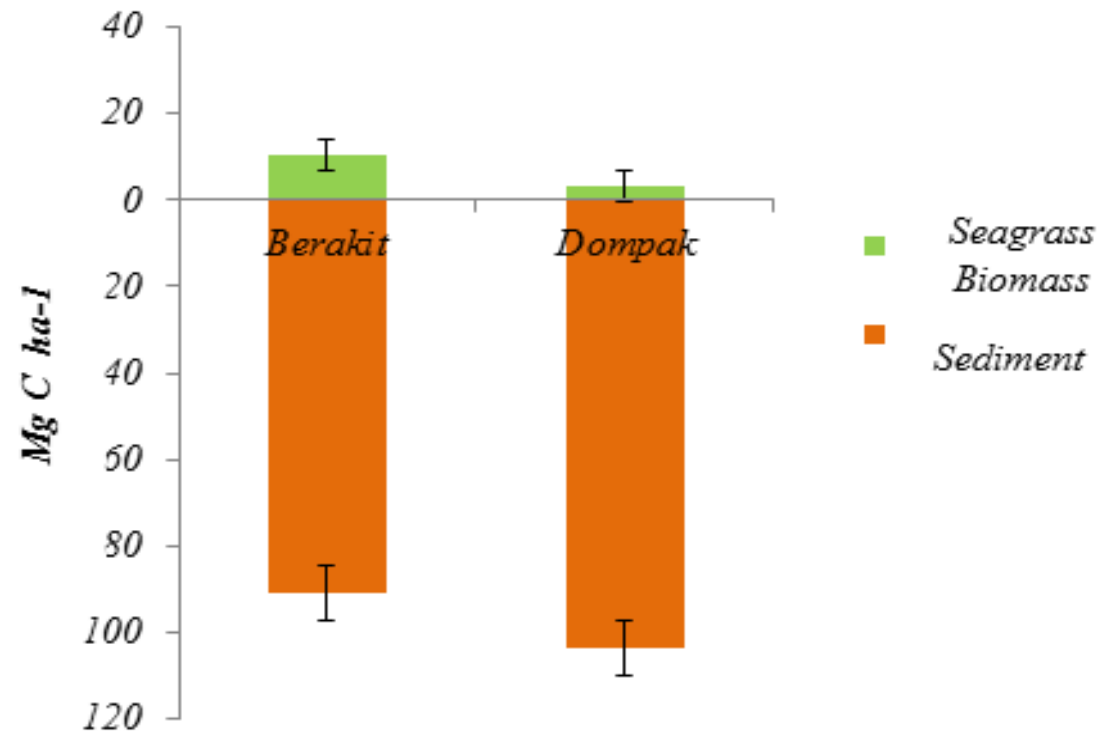

Figure 5. Carbon stock estimation in seagrass ecosystem of Dompak and Berakit.

oleh pasir. Perbedaan ukuran substrat dasar perairan berdampak terhadap proses pengikatan bahan organik, sedimen yang memiliki ukuruan partikel lebih kecil seperti lumpur mampu mengikat bahan organik yang lebih tinggi (Cyle et al., 2016). Faktor yang memengaruhi kandungan $\mathrm{C}$ organik pada substrat ekosistem lamun selain berasal dari biomassa lamun dipengaruhi juga oleh konsentrasi bahan organik pada sedimen. (Rahayu et al., 2019).

Table 3. The estimation of carbon stock on substate in others location.

\begin{tabular}{|c|c|c|}
\hline Location & $\begin{array}{c}\text { Carbon } \\
\left(M g C h a^{-1}\right)\end{array}$ & Reference \\
\hline $\begin{array}{l}\text { Bonetambung, } \\
\text { Sulawesi Selatan }\end{array}$ & 147.7 & $\begin{array}{l}\text { Yushra et } \\
\text { al. }(2020)\end{array}$ \\
\hline $\begin{array}{l}\text { Lae-Lae, } \\
\text { Sulawesi Selatan }\end{array}$ & 48.9 & $\begin{array}{l}\text { Yushra et } \\
\text { al. }(2020)\end{array}$ \\
\hline $\begin{array}{l}\text { Kepulauan } \\
\text { Speremonde }\end{array}$ & 59.3 & $\begin{array}{l}\text { Rahayu et } \\
\text { al. (2019) }\end{array}$ \\
\hline $\begin{array}{l}\text { Teluk Bakau, } \\
\text { Bintan }\end{array}$ & 75.16 & $\begin{array}{l}\text { Indriani et } \\
\text { al. }(2017)\end{array}$ \\
\hline $\begin{array}{l}\text { Pengudang, } \\
\text { Bintan }\end{array}$ & 100.05 & $\begin{array}{l}\text { Indriani et } \\
\text { al. (2017) }\end{array}$ \\
\hline
\end{tabular}

Informasi yang disajikan pada Table 3 diketahui umumnya setiap lokasi memiliki stok karbon yang berbeda pada sedimen di ekosistem lamun. Hal ini semakin menguatkan bahwasannya kondisi lingkungan yang berbeda pada setiap lokasi berpengaruh terhadap nilai stok karbon pada ekosistem lamun.

\section{KESIMPULAN}

Perairan Berakit memiliki estimasi kandungan karbon lamun yang lebih tinggi daripada Perairan Dompak, yaitu sebesar $10,58 \mathrm{Mg} \mathrm{C} / \mathrm{m}^{2}$. Sebaliknya, Perairan Dompak memiliki estimasi total cadangan karbon pada sedimen yang lebih tinggi dibandingkan Perairan Berakit 103,80 Mg Corg $\mathrm{ha}^{-1}$. Kandungan karbon lamun dipengaruhi oleh kerapatan dan biomassa, sedangkan kandungan karbon pada substrat dipengaruhi oleh ukuran partikel dan kondisi lingkungan sekitarnya.

\section{UCAPAN TERIMA KASIH}

Terimakasih kepada Balai Perikanan Budidaya Air Payau Situbondo yang telah membantu menganalisis sampel penelitian serta DIPA Universitas Maritim Raja Ali Haji Tahun Anggaran 2020 yang telah membiayai publikasi ini. 


\section{DAFTAR PUSTAKA}

Adi,W., A.H. Nugraha, Y.H. Dasmasela, A. Ramli, C.F.A. Sondak, \& N.D.M. Sjafrie. 2019. Struktur komunitas lamun di Malang Rapat, Bintan. $J$. Enggano, 4(2): 148-159. https://doi.org/10.31186/jenggano.4. 2.148-159

American Public Health Association (APHA). 2017. Standard Methods for the Examination of Water and Wastewater, $23^{\text {nd }}$ Edition. United Book Press Inc. Maryland. 1546 p.

Cyle, K.T., N. Hill, K., Young, T. Jenkins, D. Hancock, P.A. Schroeder, \& A. Thompson. 2016. Substrate quality influences organic matter accumulation in the soil silt and clay fraction. Soil Biology and Biochemistry, 103: 138-148.

https://doi.org/10.1016/j.soilbio.2016 .08 .014

Dahl, M., M.E. Aslund, M. Bjork, D. Deyanova, E. Infantes, M. Isaeus, A.N. Sandman, \& M. Gullstrom. The influence of hydrodinamic exposure on carbon storage and nutrient retention in eelgrass (Zostera marina L) meadows on the Swedish Skagerrak coast. Scientific Reports, 10(13666): 1-13.

https://doi.org/10.1038/s41598-02070403-5

Duarte, C., J. Middelburg, \& N. Caraco. 2005. Majore role of marine vegetation on the oceanic carbon cycle. Biogeosciences, 2: 1-8.

https://doi.org/10.5194/bg-2-1-2005

Feryatun, F., B. Hendrarto, \& N. Widyorini. 2012. Kerapatan dan distribusi lamun (seagrass) berdasarkan zona kegiatan yang berbeda di perairan Pulau Pramuka, Kepulauan Seribu. Management of Aquatic Resources, 1(1): 1-7. https://doi.org/10.14710/marj.v1i1.2 55
Fourqurean, J.W., C.M. Duarte, H. Kennedy, M. Marba, M. Holmer, M.A. Mateo, E.T. Apostolaki, G.A. Kendrick, D.K. Jensen, K.J. McGlathery, \& O. Serrano. 2012. Seagrass ecosystems as a globally significant carbon stock. Nature Geoscience, 5: 505-509. https://doi.org/10.1038/ngeo1477

Gemilang, W.A. \& G. Kusumah. 2017. Status indeks pencemaran perairan kawasan mangrove berdasarkan penilaian fisika-kimia di pesisir Kecamatan Brebes Jawa Tengah. Enviro. Scienteae, 13(2): 171-180. https://doi.org/10.20527/es.v13i2.39 19

Gunawan, J.V., M. Parengkuan, A.J. Wahyudi, \& F. Zulpikar. 2019. Estimasi stok karbon pada biomassa lamun di Pulau Semak Daun, Kepulauan Seribu. Oseanologi dan Limnologi, 4(2): 89-99.

https://doi.org/10.14203/oldi.2019.v4 i2.229

Halim, M., D.G. Bengen, \& T. Prartono. 2020. Influence of turbidity and water depth on carbon storage in seagrasses, Enhalus acoroides and Halophila ovalis. AACL Bioflux, 13(1): 309-317.

https://www.bioflux.com.ro/docs/20 20.309-317.pdf

Hamuna, B., R.H.R. Tanjung, S. Suwito, H.K. Maury, \& A. Alianto. 2018. Kajian kualitas air laut dan indeks pencemaran berdasarkan parameter fisika-kimia di Perairan Distrik Depapre, Jayapura. J. Ilmu lingkungan, 16(1): 35-43. https://doi.org/10.14710/jil.16.1.3543

Harimbi, K.A., N. Taufik, \& I. Ritniasih. 2019. Potensi penyimpanan karbon pada lamun spesies Cymodocea serrulata dan Enhalus acoroides di Perairan Jepara. Buletin Oseanografi Marina, 8(2): 109-115. 
https://doi.org/10.14710/buloma.v8i2 .23657

Hartati, R., I. Pratikto, \& T.N. Pratiwi. 2017. Biomassa dan estimasi simpanan karbon pada ekosistem padang lamun di Pulau Menjangan Kecil dan Pulau Sintok, Kepulauan Karimunjawa. Buletin Oseanografi Marina, 6(1): 74-81.

https://doi.org/10.14710/buloma.v6i1 .15746

Indriani, A.J. Wahyudi, \& D. Yona. 2017. Cadangan karbon di area padang lamun pesisir Pulau Bintan, Kepulauan Riau. Oseanologi dan Limnologi Indonesia, 2(3): 1-11. https://doi.org/10.14203/oldi.2017.v2 i3.99

Irawan, A. 2017. Potensi cadangan dan serapan karbon oleh padang lamun di bagian utara dan timur Pulau Bintan. Oseanologi dan Limnologi Indonesia, 2(3): 35-48. https://doi.org/10.14203/oldi.2017.v2 i3.99

Kawaroe, M., A.H. Nugraha, \& Juraij. 2016. Ekosistem Padang Lamun. IPB Press. Bogor. $114 \mathrm{p}$.

Kennedy, H., J. Beggins, C.M. Duarte, J.W. Fourqurean, M. Holmer, N. Marba, \& J.J. Middleburg. 2010. Seagrass sediments as a global carbon sink: isotopic constraints. Global Biogeochem Cycles, 24: GB4026. https://doi.org/10.1029/2010GB0038 48

Khairunnisa, I. Setyobudiandi, \& M. Boer. 2018. The estimation of segrass carbon stock in the east coast of Bintan Regency. J. Ilmu dan Teknologi Kelautan Tropis, 6(3): 639-650. http://doi.org/10.29244/jitkt.v10i3.21 397

Lanuru, M., W. Samad, K. Amri, \& D. Priosambodo. 2018. Oceanographic conditions and sediment dynamic of the Barrang Caddi Island
(Spermonde Archipelago, Indonesia). Conf. Ser.: Earth Environ. Sci., 157(012040): 1-6. http://doi.org/10.1088/17551315/157/1/012040

Lavery, P.S., M.A. Mateo, O. Serrano, \& M. Rozaimi. 2013.Variability in the carbon storage of seagrass habitats and its implications for global estimates of blue carbon ecosystem service. PLoSONE, 8(9): e73748. https://doi.org/10.1371/journal.pone. 0073748

Nugraha, A.H., M. Kawaroe, E.S. Srimariana, I. Jaya, D. Apdillah, \& S.R. Deswati. 2019a. Carbon storage in seagrass meadow of Teluk Bakau - Bintan Island. IOP Conference Series: Earth and Environmental Science, 278: 1-6. https://doi.org/ 10.1088/17551315/278/1/012051

Nugraha, A.H., E.S. Srimariana, M. Kawaroe, \& I. Jaya. 2019b. Struktur ekosistem lamun di desa Teluk Bakau, pesisir bintan timurIndonesia. Depik J. Ilmu-Ilmu Perairan, Pesisir dan Perikanan, 8(2): 87-96.

https://doi.org/10.13170/depik.8.2.13 422

Paty, S.I. 2013. Distibusi suhu, salinitas, dan oksigen terlarut di Perairan Kema Sulawesi Utara. Platax, 1(3): 148157.

https://doi.org/10.35800/jip.1.3.2013. 2580

Rahayu, Y.P., T. Solihuddin, M.A. Kusumaningtyas, R.N.A. Ati, H. Salim, T. Rixen, \& A.A. Hutahaean. 2019. The sources of organic matter in seagrass sediments and their contribution to carbon stock in Spermonde Islands, Indonesia. Aquatic Geochemistry, 25: 161-178. https://doi.org/10.1007/s10498-01909358-7

Rahmawati, S., A. Irawan, H.I. Supriyadi, \& 
M.H. Azkab. 2017. Panduan Monitoring Padang Lamun. COREMAP-CTI LIPI. Jakarta. $32 \mathrm{p}$

Rahmawati, S., U.E. Hernawan, \& A. Rustam. 2019a. The seagrass carbon content of 0.33 dry weight can be applied in Indonesia seagrasses. AIP Conference Proceedings: International Conference on Biology and Applied Science (ICOBAS), 2120: 17. https://doi.org/10.1063/1.5115616

Rahmawati, S., U. Hernawan, K. Mcmahon, B. Prayudha, H.B. Prayitno, A.J. Wahyudi, \& M. Vanderklift. 2019b. Blue Carbon in Seagrass Ecosystem: Guideline for The Assessment of Carbon Stock And Sequestration In Southheast Asia. 2019b. Asean Sub Committee on Marine Science and Technology (SCMSAT). Indonesia. $112 \mathrm{p}$.

Repolho,T., B. Duarte, G. Dinosio, J.R. Paula, A.R. Lopes, I.C. Rosa, T.F. Grilo, I. Cacador, R. Calado, \& R. Rosa. 2016. Seagrasseophysiological performance under ocean warming and acidification. Sci. Rep., 7: 41443. https://doi.org/10.1038/srep41443

Rustam, A., N. Sudirman, R.N.A. Ati, H.L. Salim, \& Y.P. Rahayu. 2017. Seagrass ecosystem carbon stock in the small islands: case study in Spermonde island, South Sulawesi, Indonesia. J. Segara, 13(2): 97-106. https://doi.org/10.15578/segara.v13i 2.6445

Sarinawaty, P., F. Idris, \& A.H. Nugraha. 2020. Karakteristik morfometrik lamun Enhalus acoroides dan Thalassia hemprichii di Pesisir Pulau Bintan. J. of Marine Research , 9(4): 478-484. https://doi.org/10.14710/jmr.v9i4.28 432

Sarmiento, J.L. \& N. Gruber. 2002. Sink for anthropogenic carbon. Physics today, 55(8): 30-36.

https://doi.org/10.1063/1.1510279
Sjafrie, N.D.M., L. Adrianto, A. Damar, \& M. Boer. 2017. Human appropriation of net primary production (HANPP) in seagrass ecosystem: an example from the eest coast of Bintan Regency, Kepulauan Riau Province, Indonesia. Enviro. Dev. Sustain., 20: 865-881. https://doi.org/10.1007/s10668-0179914-z

Supriadi, R.F. Kaswadji, D.G. Bengen, \& M. Hutomo. 2014. Carbon stock of seagrass community in Barranglompo Island, Makassar. J. Ilmu Kelautan, 19(1): 1-10.

https://doi.org/10.14710/ik.ijms.19.1. 1-10

Wahyudi, A.J., S. Rahmawati, B. Prayudha, M.R. Iskandar, \& T. Arfianti. 2016. Vertical carbon flux of marine snow in Enhalus acoroides dominated seagrass meadows. Regional Studies in Marine Science, 5: 27-34.

http://doi.org/10.1016/j.rsma.2016.0 1.003

Wahyudi, A.J., S. Rahmawati, A. Irawan, H. Hadiyanto, B. Prayudha, M. Hafizt, A. Afdal, N.S. Adi, A. Rustam, U.E. Hernawan, Y.P. Rahayu, M.Y. Iswari, I.H. Supriyadi, T. Solihudin, R.N.A. Ati, T.L. Kepel, M.A. Kusumaningtyas, A. Daulat, H.L. Salim, N. Sudirman, D.D. Suryono, \& W. Kiswara. 2020. Assesing carbon stock and sequestration of the tropical seagrass meadows in Indonesia. Ocean Science J., 55: 8597.

https://doi.org/10.1007/s12601-0200003-0

Yushra, G.H., Adiguna, L.W. Sasongko, \& R.P. Widyastuti. 2020. Estimasi stok karbon sedimen area padang lamun di kepulauan Spermonde, Sulawesi Selatan. Manafish J., 1(1): 43-57. https://ejurnal.polnep.ac.id/index.php /manfish/article/view/41 
Estimasi Kandungan Stok Karbon pada Ekosistem Padang Lamun di ...

Received : 14 October 2020

Reviewed : 3 November 2020

Accepted : 20 December 2020 